\title{
İş Doyumunun Tükenmişlik Düzeyine Etkisinde Örgütsel Sessizliğin Aracılık Rolü: TRC1 AFAD Çalıșanları Örneği
}

The Role of Organizational Silence in the Effect of Job Satisfaction on the Level of Burnout: The Case of TRC1 AFAD Employees

\author{
İsmail Turgut PALA ${ }^{1}$, Mehmet Hanefi TOPAL ${ }^{2}$, Orkun DEMİRA $\breve{G}^{3}$
}

\begin{abstract}
ÖZ
AFAD personelleri yoğun çalışma temposu, uzun çalışma saatleri, fazla iş yükü sebebiyle yüksek strese maruz kalmaktadırlar. $\mathrm{Bu}$ şartlar göz önünde bulundurulduğunda, çalışma koşullarının personeli psikolojik anlamda zaman zaman yorduğu düşünülmektedir. $\mathrm{Bu}$ bağlamda, Suriye insani krizi nedeniyle yoğun göç almış bölgelerde Adıyaman, Gaziantep, Kilis İl Afet ve Acil Durum Müdürlüklerinde görev yapan personellerinin iş doyumu, örgütsel sessizlik ve tükenmişlik düzeylerinin belirlenmesi ve iş doyumunun tükenmişlik üzerine etkisinde örgütsel sessizliğin aracılık etkisini belirlemeyi amaçlamıştır. Nicel araştırma deseni olan çalışmamız 101 çalışan ile yürütülmüştür. Araştırmada "Tanıtıcı Bilgi Formu", "İ̧s Doyumu Ölçeği", “Tükenmişlik Ölçeği” ve “Örrgütsel Sessizlik Ölçeği” kullanılmıştır. Araştırma sonucuna göre iş doyumu ile tükenmişlik arasındaki ilişkide örgütsel sessizliğin kısmi aracılık etkisi olup, örgütsel sessizlik bu iki olgu arasındaki negatif ilişkiyi zayıf da olsa etkisini azaltmaktadır.
\end{abstract}

Anahtar Kelimeler: AFAD çalışanları, İş Doyumu, Örgütsel sessizlik, Tükenmişlik

\begin{abstract}
Republic of Turkey, Ministry of Interior, Disaster and Emergency Management Presidency (AFAD) personnel are exposed to high stress due to high working tempo, long working hours, and heavy workload. Considering these conditions, it is thought that working conditions tire the staff psychologically from time to time. Our work which we started with this hypothesis aims not only to figure out levels of job satisfaction, organizational silence and burnout of the personnel who works at the provincial disaster and emergency directorates of Adiyaman, Gaziantep and Kilis where a great number of people immigrated due to Syrian crisis, but also targets to reveal mediation of organizational silence on the effect of job satisfaction on burnout. This work with quantitative research pattern performed with 101 personnel. In this research "introductory information form", "job satisfaction scale", "burnout scale" and "organizational silence scale" are used. According to results of the research, organizational silence has a partial mediation on the relation of job satisfaction and burnout and organizational silence moderates the negative relation between these two phenomena at the least.
\end{abstract}

Keywords: AFAD personnel, Job satisfaction, Organizational silence, Burnout

Bu çalıșa İsmail Turgut PALA'nın Mehmet Hanefi TOPAL danıșmanlı̆̆ında yürüttüğü "İs Doyumunun Tükenmişlik Düzevine Etkisinde Örgütsel Sessizliğin Aracllık Rolü: Trc1 Afad Çalışanlarl Örneğgi” başllkl yüksek lisans tezinden üretilmişstir. Çalı̧̧manın etik izni Gümüşhane Üniversitesi Bilim Etik Onay Kurulunun 30.10.2018 tarih ve 2018/08 sayılı kararı ile alınmıştır.

${ }^{1}$ Öğr. Gör., İsmail Turgut PALA, Afet Yönetimi, Trabzon Üniversitesi Şalpazarı Meslek Yüksekokulu Mülkiyet Koruma ve Güvenlik Bölümü, turgut.pala@trabzon.edu.tr, ORCID: 0000-0002-9367-6928

${ }^{2}$ Doç. Dr., Mehmet Hanefi TOPAL, Maliye, Kırklareli Üniversitesi İktisadi ve İdari Bilimler Fakültesi Maliye Bölümü, mtopal@klu.edu.tr, ORCID: 0000-0003-4014-8694

${ }^{3}$ Dr. Öğr. Üyesi, Orkun DEMIRBAĞ, Yönetim ve Organizasyon, Gümüşhane Üniversitesi İktisadi ve İdari Bilimler Fakültesi İşletme Bölümü, orkundemirrbag@gmail.com, ORCID: 0000-0001-9889-3406 


\section{GIIRIŞ}

Türkiye coğrafi konumu itibariyle sik sik doğal afetler ile yüz yüze kalırken, jeopolitik konumu sebebiyle de KBRN (Kimyasal Biyolojik Radyolojik Nükleer) kazaları, göç gibi insan kaynaklı afetlerle mücadele etmek zorunda kalan bir ülkedir. Ani ve öngörülemeyen bu afetler toplumsal ve ekonomik yıkımlara neden olmaktadır. Bireylerin ve toplumların çaresiz kaldığı bu yıkımlardan bir an önce normal hayata dönüşe hizmet eden kamu kurumları etkin rol almaktadır. Kamu örgütlerinin hizmet kalitesi yüksek faaliyetlerde bulunabilmeleri yeniliklere açık olmalarına ve teknolojik gelişmeleri takip etmelerine bağlıdır. Yaşanan değişimler örgütleri maddi ve manevi sıkıntılara sokabilmektedir. $\mathrm{Bu}$ değişim ve sıkıntılarla baş etme büyük ölçüde insan kaynaklarıyla üstesinden gelinmektedir. Dolayısıyla kurumun etkin ve verimli çalışmasının sürdürülebilir olması için insan kaynaklarının önemli bir yere sahip olduğu söylenebilir. Yöneticilerin çalışanlarının motivasyonu ve mutluluğu üzerinde durması gerektiğinin bilincinde olması gerekir. Afetler ile mücadele eden kamu kurumları arasında Afet ve Acil Durum Yönetimi Başkanlığ (AFAD) en önemli yere sahiptir. AFAD'ın başarılı olmasının arkasında insan kaynaklarının etkin çalışması yer almaktadır. Afet kaynaklı yıkımlara tanık olmak ya da afetzede olmak çoğu insan için olumsuz etkiye neden olurken, bu yıkımların bertaraf edilmesinde etkin olarak görev almak acil durum çalışanları için önemli bir doyum kaynağıdır.

Her çalışan yaptığı işten doyum almak istemektedir. Bu da insan kaynaklarını etkili kullanarak çalışanların mutluluğunu ve verimini artırarak mümkün olabilmektedir. Çalışanlar bir konu hakkındaki görüş ve düşüncelerini özgürce paylaşabildikleri ortamda doyumu ve verimini artacağı düşünülmektedir. Çalışanların sessiz kaldıkları bir ortam da ise doyumun azalmasının yanı sıra günümüzde stresli çalışma koşulları neticesinde görülen tükenmişlik sendromuna da yakalanması mümkündür. Çalışanların iş doyumunun azalması, kurum içerisinde sessizliği tercih etmesi ve sonuç olarak tükenmesi bu personellerin verimi azaltacaktır. $\mathrm{Bu}$ durum ise kurumda maddi manevi kayıplara neden olacaktır.

Genel olarak iş doyumu; işi yapan kişilerin çalıştı̆̆ 1 kurumdan, yaptığ memnun olma durumudur. İş doyumu olan kişinin verimliliği ve performansı da artmaktadır. Buna bağlı olarak; kurumda da verimliliği artacağından, iş doyumu hem kurum için hem de çalışan için önemli bir durumdur. ${ }^{1}$ İş doyumu ilgili yaklaşımlardan Vroom'un Bekleyiş Kuramında; kişinin vereceği emek ona ödül kazandıracağına inanmalıdır. Kişi başarı neticesinde ona verilecek olan ödülü istemelidir. $\mathrm{Bu}$ ödül birey için kıymetli (valance) olmalıdır. Kişi beklenen başarıyı elde edeceğine inanmalıdır. Bekleyiş kuramında başarı ödüllendirilmiş davranış sayesindedir. ${ }^{2}$ Örgütsel sessizlik bağlamında çalışanlar kurum içerisindeki yönetimin tutumuna bağlı olarak farklı davranışlar gösterebilir. Demokratik bir ortamda birey rahat bir şekilde kendisini ifade etmek imkânı bulacaktır. Çalışan için bu seslilik ödüle ulaşmasında engel olmadığının farkındadır. Ancak otoriter yönetim tarzında ise ödüle ulaşmak adına çalışanlar sessizliği tercih edebilirler. Tükenmişlik bağlamında ise verilen her emeğe karşı ödülün bulunması çalışanın tükenmeye dirençli olmasını ve yaptığı işten doyum almasını sağlayacaktır.

Tükenmişlik kavramı Psikolog Freudenberger tarafından çalışma yaşamında istek ve enerjinin azalması, başarılı olamama, yıpranma ve karşılanması zor taleplerin bireyde oluşturduğu yük ile bireyin içsel kaynaklarının tükenmesi, şeklinde tanımlanmıştır. Christina Maslach ise tükenmişlik sendromunu; kronik olarak insanlar arasında stres oluşturma potansiyellerine karşı gelişen psikolojik sendromdur. Üç boyuttan meydana gelir. Maslach'ın tükenmişlik modelinde birinci boyut duygusal tükenme kişinin kendisini umutsuz bitkin ve yorgun hissetmesidir. 
Yapılan iş ve verilen hizmette meydana gelen duyarsızlaşma ise ikinci boyutudur. Kişi sadece mekanik olarak görevini yapar. Son boyut ise başarı duygusunun yitirilmesidir. Kişi başarısız olduğundan dolayı kendisini suçlar. Tükenmişlik yaşamayan kişilerde bunların yerine enerji, aidiyet ve yeterlilik duyguları meydana gelir. ${ }^{3}$ Duygusal tükenme yaşayan çalışan kendisini yorgun ve bitkin hissedecek, zamanla duyarsızlaşmaya başlayıp, kişi çevresiyle sosyal ilişki kurmadan çevresine karşı sessizleşip sadece işini yapacaktır. Artık yaptığı işi başaramadiğ 1 düşüncesi çalışanda hâkim olup işten aldığı doyum da azalacaktır. Çalışma konumuz olan AFAD çalışanlarını böyle bir durumda enkazda yaralı kurtarmaya bitkin ve yorgun bir şekilde gidecektir. Bu durum enkaz altındakilerle iletişim kurmasının önüne engel oluşturacak ve afetzedelerin sakinleştirilmesi gibi işin önemli bir parçasını atlamasına neden olabilecektir. Çalışan makinenin bir parçası olduğunu düşündüğünü varsaydığı için işinden bir tatminde alamayacaktır.

İş doyumu yüksek olan çalışanlar kurum için fedakârlıkla görev yapacaktır. Aksi durumdaysa çalışan sadece kendisini tükenmiş hissetmekle kalmayacak diğer çalışanları ve hizmet verdiği kişileri de olumsuz etkileyecektir. Bu durum kurumun işleyişi noktasında aksaklıklara sebep olurken büyük ölçekte kamu hizmetlerinde aksamasına neden olacaktır. Kişilerin tükenmişlik nedeniyle işten ayrılmaları yetişmiş iş gücü kaybına sebep olabileceği de göz önünde bulundurularak, yönetici konumundaki kişilerin var olan insan kaynağını doğru yönetebilmek adına çalışanlarına gelişme şansı sağlaması faydalı olacaktır. $^{4}$

Tükenmişliğin çalışanlar içindeki yaygınlığını ortaya koymak adına yapılan alan taramasında çeşitli çalışmalar dikkat çekmektedir. Çat'ın (2014) ve Koç'un (2019), acil yardım, kurtarma ve müdahale personelleri üzerine yaptığ 1 çalışmalarda, Karacaoğlu ve Çetin'in (2015) ve Vural'ın (2016) AFAD çalışanları üzerinde yaptığı araştırmalar da; AFAD personellerinin tükenmişlik seviyeleri orta değere yakın olduğu belirlenmiştir. Ayrıca Aslan Aydın'ın (2019), Koç'un (2019) ve Öztürk'ün (2018) sağlık çalışanlarına yönelik çalışmasında ve Sarıtaş'ın (2015) itfaiye çalışanları üzerinde yaptığı araştırmada katılan personellerin tükenmişlik ile iş doyumu puan ortalamaları arasında negatif yönde anlamlı bir ilişki olduğu belirlenmiştir.

Örgütsel sessizlik ise örgüt problemleri hakkındaki fikir, görüş ve endişelerin gerçekleştirilmeme durumudur. ${ }^{13}$ Örgütsel sessizlik kurum için mali ve emek tasarrufu yönünden etkin süreçtir. Örgütsel sessizlik örgüt içindeki karar mekanizmasını harekete geçirmektedir. Çevre ile uyum sağlayıp örgütün devamlılığını sağlamaktadır. Örgüt içerisindeki sorunları da tanımlamasına katkıda bulunmaktadır. ${ }^{14}$ Örgütsel sessizlik teorilerinden sessizlik sarmalı teorisinde çalışanların iş arkadaşlarından destek almadıkça sessizliği tercih edeceği bahsedilmektedir. Eğer çalışanlar iş arkadaşlarından destek alacağına inancı yok ise veya ses çıkartmaya direnç göstereceklerini düşünüyorsa, büyük ihtimalle dürüst olmayan bir yanıtı veya sessizliği tercih edeceklerdir. Grup içindeki sessizlik sarmalı, örgütün iyileştirilmesi için yapılacak açı ve dürüst tartışmaları kısıtlayabilir. Çalışanları, fikirlerini ifade etmekten, düşüncelerinde açık ve dürüst olmaktan alıkoyan, izolasyon tehdidi ve korkusudur. Örgüt içerisinde sessiz kalma ve konuşma arasındaki seçimi, büyük ölçüde etkileyen çalışma grubundaki egemen görüş ve algılanan örgütsel destektir. ${ }^{14}$

İş görenler için sessiz kalmanın bazı riskleri olabilir. Zamanla, sorunlar ve endişeler hakkında konuşamama hissi, çaresizlik hissinin yanı sıra iş doyumu alamama, işten ayrılma gibi sonuçlar doğurabilir. ${ }^{15}$ Kurum devamlılığı için insan kaynakları önemli bir faktördür. Çalışanların tükenmişlik ve sessizlik ile karşılaşması durumu kuruma zarar verebilir. Kurum içerisinde tükenmişlik ve örgütsel sessizlik yaşanmaması için başta yönetim olmak üzere kurumun tüm yapısında çalışanlar desteklenmeli ve örgütün bir parçası 
olduklarını hissetmelidirler. ${ }^{16} \mathrm{Bu}$ bağlamda örgüt içerisinde söz hakkı tanınan, yönetime katılan çalışanların yaptıkları işten doyum alacakları ve tükenmeye karşı dirençli olacakları öngörülmektedir. İletişim ortamının sağlıklı olmadığı örgütlerde başarıyı elde etmek kolay değildir. Çalışanların sessizlik davranışları o örgütte sağlıklı iletişim olup olmadığının göstergesidir. Örgüt içerisinde sessizliğin baskın olarak yerleşmesi çalışanlar açısından yüksek tükenmişlik ve düşük iş doyumuna neden olduğu düşünülmektedir. ${ }^{17}$

Konuyla ilgili yapılan alan taramasında; Birmiş, Ergeneli ve Oktay'ın (2018) afet ve acil durum yönetimi çalışanları üzerine yaptığı çalışmada örgütsel sessizlik düzeylerinin orta seviyeye yakın olduğu saptanmıştır. Turgut ve Akpolat'ın (2017) sağlık çalışanları üzerine yaptığı araştırmada ve Kaya'nın (2020) hemşireler üzerine yaptığ faktörleri arasında en yüksek ortalamanın örgüt yararına sessizlik olduğunu saptamışlar. Ayrıca Karkı'nın (2017) ve Aktaş ve Şimşek'in (2015) kamu personelleri üzerine yaptığı çalışmada örgütsel sessizlik ile iş doyumu arasında anlamlı negatif ilişki bulmuştur. Demirtaş ve Nacar'ın (2018) öğretmenler üzerine yaptığı çalışmada örgütsel sessizlik ile iş doyumu arasında anlamlı ilişki bulunamamıştır. Egi'nin (2019) öğretmenler üzerine yaptığı çalışmada örgütsel sessizlik ile iş doyumu arasında anlamlı pozitif yönde ilişki bulmuştur. Doğan ve Kır'ın (2018) sağlık çalışanlarına yönelik yaptığı çalışmada örgütsel sessizlik ve tükenmişlik arasında anlamlı ilişki bulunmamıştır. Aktaş ve Şimşek'in (2015) kamu personelleri üzerine yaptığı çalışmada örgütsel sessizlik ile tükenmişlik arasında anlamlı negatif ilişki bulmuştur. Kahya'nın (2015) akademisyenler üzerine yaptığ Burulday'ın (2018) ve Çitli'nin (2015) öğretmenler üzerine yaptığ 1 araștırmada örgütsel sessizlik ile tükenmişlik arasında pozitif yönde anlamlı ilişki bulmuştur.

$\mathrm{Bu}$ bağlamda literatür incelendiğinde, iş doyumu, örgütsel sessizlik ve tükenmişlik konusu ile ilgili AFAD çalışanlarına yönelik çalışmaların kısıtlı olduğu ve bu 3 değişken birlikte irdelendiği çalışmaların nadir olduğu görülmüştür.

$\mathrm{Bu}$ durum göz önüne alarak çalışmamız AFAD çalışanların iş doyumu, örgütsel sessizlik ve tükenmişlik düzeylerini belirlemek ve iş doyumunun tükenmişlik düzeyine etkisinde örgütsel sessizliğin aracılık rolünü incelemeyi amaçlamıştır. $\mathrm{Bu}$ amaçla hareketler araştırmanın hipotezi:

$\mathbf{H}_{1}$ : İş doyumunun tükenmişlik üzerindeki etkisinde örgütsel sessizliğin aracılık rolü vardır.

Elde edilen sonuçlar ile politika üreticilerine, yeni araştırmacılar ve literatüre katkı sağlayıp, görüş ve öneriler geliştirilecektir.

\section{MATERYAL VE METOT}

\section{Araştırmanın Tipi}

Araştırma nicel araştırma yöntemi olup, tarama modeli kullanılmıştır. Genel tarama modelleri, çok sayıda elemandan oluşan bir evrende, evren hakkında genel bir yargıya varmak amaciyla evrenin tümü ya da ondan alınacak bir grup, örnek ya da örneklem üzerinde yapılan tarama düzenlemeleridir. ${ }^{28}$

\section{Araştırmanın Evren ve Örneklemi}

Araştırmanın evreni Adıyaman, Gaziantep ve Kilis İlleri Afet ve Acil Durum Müdürlüklerinde görev yapan AFAD personelidir. Anket form Adiyaman, Gaziantep ve Kilis İl Afet ve Acil Durum Müdürlüklerinde görev yapan personeller ile yüz yüze görüşme yoluyla doldurulmuştur. Ancak katılmak istemeyen ve o tarihler arasında izinli olduğu için ankete katılmayan AFAD çalışanları olmuştur. Araştırmaya yukarıda sayılan nedenlerden dolayı ancak 101 kişi katılmıştır.

\section{Verilerin Toplanması}

Araştırmanın verileri Adıyaman, Gaziantep ve Kilis İl Afet ve Acil Durum Müdürlüklerinden gerekli izinler alındıktan 
sonra 26.11.2018 - 10.12.2018 tarihleri arasında yüz yüze görüşme yoluyla toplanmıştır. AFAD çalışanlarına araştırmanın kapsamına ve amacına yönelik gerekli bilgiler verilmiş olup çalışanların mahremiyetine özen gösterilmiştir.

\section{Veri Toplama Araçları}

Araştırmada veriler yüz yüze uygulanan anket yöntemiyle toplanmıştır. Anket formunun ilk kısmında iş doyum, tükenmişlik ve örgütsel sessizlik ölçeklerinin soruları yer almaktadır. Anket formunun ikinci kısmında ise araştırmacı tarafından hazırlanan ve katılımciların niteliklerini ortaya koyan taniticı bilgi formu soruları yer almaktadır.

Tanıtıcı bilgi formundaki sorular, katılımcıların çalıştıkları il, cinsiyetleri, yaşları, eğitim durumları, haftalık çalışma süreleri, hizmet birimleri, çalıştıkları şube, aylık gelirleri ile gelirlerini yeterli görüp görmediklerine, mesleklerini isteyerek mi seçtiklerine, firsatları olsa işlerini değiştirmek isteyip istemediklerine ve meslekleriyle ilgili görüş ve önerilerine dair sorulardan oluşmaktadır.

Araştırmada katılımcıların iş doyum düzeyini ölçmek için Minnesota İş Doyum Ölçeği kullanılmıştır. Minnessota İş Doyum Ölçeği, Weiss, Davis, England ve Lofguist (1967) tarafından geliştirilmiş olup Baycan (1985) tarafından Türkçeye uyarlanarak geçerlilik ve güvenirlik çalışmaları yapılmıştır. İş doyum ölçeğinin orijinal formu 5 noktalı skala şeklinde olup bu araştırmada yanıtlar 7'li likert tipine çevrilmiştir. $\mathrm{Bu}$ ölçekte ters puanlama bulunmamaktadır. Toplam 20 sorudan oluşan ölçek, içsel doyum ve dişsal doyum düzeylerini ölçmektedir. Puanlama sisteminde kullanılan her ifade için hiç memnun değilim; 1 puan, memnun değilim; 2 puan, kısmen memnun değilim; 3 puan, kararsızım; 4 puan, kısmen memnunum; 5 puan, memnunum; 6 puan, çok memnunum; 7 puan verilerek değerlendirilmektedir.

Katılımcıların tükenmişlik düzeylerini belirlemek için kullanılan Pines ve Aronson (1988) tarafından geliştirilen tükenmişlik ölçeği Çapri (2006) tarafından Türkçeye uyarlanarak geçerlilik ve güvenirlik çalışmaları yapılmıştır. Ölçek maddeleri "1 hiçbir zaman" ve "7 her zaman" biçiminde puanlanmaktadır. Ölçeğin duygusal tükenme, zihinsel tükenme ve fiziksel tükenme olmak üzere 3 alt boyutu vardır.

Katılımcıların örgütsel sessizlik düzeyinin belirlenmesi amaciyla 14 maddeden ve 3 alt boyuttan (kabul edici, savunma amaçlı, örgüt yararına) oluşan örgütsel sessizlik ölçeği kullanılmıştır. Ölçek Van, Ang ve Botero (2003) tarafından geliştirilmiş ve Şehitoğlu (2010) tarafından da Türkçeye uyarlanmıştır. Ölçek maddeleri "1 tamamen katılmıyorum" ve "7 tamamen katıliyorum" biçiminde puanlanmaktadir.

\section{Araştırmanın Etik Yönü}

Çalışmada kullanılan 3 ölçek için ölçek sahiplerinden e-posta yoluyla kullanım izni alınmıştır. Çalışmanın gerçekleştiği Adiyaman İ Afet ve Acil Durum Müdürlüğü'nün 04.12.2018 tarihli, Gaziantep İl Afet ve Acil Durum Müdürlüğü'nün 27.11.2018 tarihli ve Kilis İl Afet ve Acil Durum Müdürlügü'nün ise 26.11.2018 tarihli personellere yönelik anket uygulayabilme olurları alınmıştır. Çalışma kapsamında Gümüşhane Üniversitesinden 30.10 .2018 tarihli Etik Kurul Raporu da alınmıştır.

\section{Verilerin Analizi}

Araştırmada toplanan veriler çok değişkenli istatistiksel yöntemler kullanılarak analiz edilmiştir. Öncelikle örneklemi ve yanıtları tanımlamak üzere frekans analizleri yapılmıştır. Araştırma modellerinde yer alan değişkenler arasında istatistiksel ilişki olup olmadığını eğer ilişki varsa ilişkilerin gücü ve yönü hakkında fikir elde etmek için Pearson-korelâsyon analizi uygulanmıştır. Araştırmada ölçeklerin güvenirliliği Cronbach Alfa katsayısı dikkate alınarak, yapı geçerliliği ise Açımlayıcı Faktör Analizi (AFA) ile incelenmiştir. Araştırma kullanılan ölçeklerin alt boyutlarının birbiri ile ilişkisini belirlemek amaciyla korelasyon analizlerinden yararlanılmıştır. İş doyumu, örgütsel sessizlik ve tükenmişlik düzeyleri arasında anlamlı ilişki olup olmadığını ilişki 
analizi SPSS 21.0 paket programları ile regresyon analizi uygulanmıştır. Verilerin gerçekleştirilmiştir.

\section{BULGULAR VE TARTIŞMA}

Örneklemin genel özelliklerine ilişkin bulgular Tablo 3.1.'de verilmiştir. Buna göre katılımciların \%38.6's1 (n=39) Kilis İl Afet ve Acil Durum Müdürlüğünde, \%32.7'si $(\mathrm{n}=33)$ Gaziantep Il Afet ve Acil Durum Müdürlüğünde ve \%28.7'si $\quad(n=29)$ Adiyaman İl Afet ve Acil Durum Müdürlüğünde görev yapan yapmaktadır. Katılımcıların çoğunluğu $(\% 80,2)$ erkektir. Yaş özelliklerine bakıldığında \%47,5 $(\mathrm{n}=48)$ oranla en çok katılımcının 26-35 yaş aralığında olduğu, en az katılımcının ise $\% 1,9 \quad(\mathrm{n}=2)$ oranla $18-25$ yaş aralığında olduğu görülmektedir. Katılımcıların \%13,9'u (n=14) lise, \%28,7'si (n=29) ön lisans, \%49,5'i (n=50) lisans, \%7,9'u (n=8) yüksek lisans ve doktora mezunudur. Katılımcıların çoğu \%59,4'ü (n=8) 3.500 TL ve üzeri gelir düzeyine sahiptir. Katılımciların \%59,4'ü $(n=60)$ haftada 40 saat çalışırken, \%40,6's1 (n=41) haftada 41 saat ve üzeri çalışmaktadır. Katılımcıların \%49,5'i (n=50) Teknik Hizmetler, \%41,6's1 $(\mathrm{n}=42)$ Genel İdari Hizmetler sinifinda çalışmaktadır. Katılımcıların \% 35,6'sı $(\mathrm{n}=36)$ Yönetim Hizmetleri Şubesinde, \%38,6's1 (n=39) Afet ve Acil Durum Yönetim Merkezi Şubesinde ve \%25,7'si $(\mathrm{n}=26) \quad$ Planlama, Risk Azaltma ve İyileştirme Şubesinde çalışmaktadır. Katılımcıların büyük bir çoğunluğu, \%72,3'ü $(n=73)$ gelirini yeterli görmemektedir. Yine katılımcıların büyük bir çoğunluğu \%78,2'si $(n=79)$ mesleğini isteyerek seçmiştir. Her iki katılımcıdan biri imkânı olsa mesleğini değiştirmek istemektedir.

Tüm ölçeklerin çarpıklık ve basıklık testi uygulanmış olup, bulgulara göre yalnızca iş doyumu ölçeğinden beşinci soruya ait çarpıklık ve basıklık değerini oldukça yüksek olduğu görülmüş, diğer tüm soruların dağılımının normale yakın olduğu belirlenmiştir. Dolayısıyla iş doyumu ölçeğinden beşinci soru çıkarılmıştır.

Ayrıca bir maddenin faktör yükü değerinin $\quad 0,30$ ’un üzerinde olması gerekmektedir. ${ }^{35} \mathrm{Bu}$ çalışmada da faktör yükü 0,30 üzeri olan değerler kabul edilmiştir.

İş doyumu ölçeğinin geçerliliğini ve güvenirliliğini belirlemek amaciyla uygulanan ve sirasiyla AFA ile Cronbach Alfa testinin sonuçları Tablo 1'de verilmiştir. Uygulanan AFA sonucunda elde edilmiş tanısal testlerin sonuçları ile alt faktörler arası korelasyon analizi sonuçları Tablo'nun alt kısmında görülmektedir. Verinin faktör analizine uyumlu olması için korelasyon matrisinin determinantının sıfıra eşit ya da en azından çok yakın olması, KMO değerinin 0,70 üzeri olmas1 ve Barlett testine göre temel hipotezin reddedilmiş olması gerekmektedir. Diğer tanısal testler ise faktörlerin üst yapının yüzde kaçını açıkladığını, ölçeğin ortalamasını, ölçeğin eğiklik ve basıklık değerlerini ve normal dağılıma ilişkin Shapiro-Wilk testi sonucunu vermektedir. Tanısal testlerin sonuçlarına göre korelasyon matrisinin determinantı 0'a çok yakın bir değerdir. Hesaplanan KMO değeri, 0.850 gibi oldukça iyi bir değerdir ve Barlett testi sonucuna göre korelasyon matrisinin birim matris ile aynı olduğu iddiasındaki temel hipotez de reddedilmiştir $(p=0.000)$. Ayrıca eğiklik ve basıklık değerleri makul sınırlar içerisinde olup Shapiro-Wilk testinin sonucuna göre normal dağılım temel hipotezi reddedilememiștir (ist=0,988; $\mathrm{p}=0,489$ ). Uygulanan AFA sonuçlarına göre genel olarak tüm değişkenlerin kuramsal olarak beklenilen faktörler altında toplandıkları ve ayrıca tüm değişkenlerin faktör yüklerinin de yüksek olduğu görülmektedir. AFA sonuçlarına göre, iş doyumu ölçeği 2 boyut (faktör)'tan oluşan bir yapıdır. Bu sonuçlara göre veri ve model uyumu sağlanmış olup yapı geçerliliği bulunmaktadır. Ayrıca elde edilen 2 faktör, iş doyumunun üst yapisinın varyansinın yaklaşık \% 56,229'unu açıklamaktadır. 
Tablo 1. İş Doyumu Ölçeği İçin Geçerlik ve Güvenirlik Analizi Sonuçları

\begin{tabular}{|c|c|c|c|c|c|c|c|}
\hline \multirow[b]{2}{*}{$\begin{array}{l}\text { Soru } \\
\text { No }\end{array}$} & \multirow[b]{2}{*}{$\begin{array}{l}\text { Faktörler ve } \\
\text { İfadeler (kısaca) }\end{array}$} & \multicolumn{3}{|c|}{ Faktör 1} & \multicolumn{3}{|c|}{ Faktör 2} \\
\hline & & $\begin{array}{l}\text { Faktör } \\
\text { Yükü }\end{array}$ & Özdeğer & $\begin{array}{c}\text { Açıklanan } \\
\text { Varyans }\end{array}$ & $\begin{array}{c}\text { Faktör } \\
\text { Yükü }\end{array}$ & Özdeğer & $\begin{array}{c}\text { Açıklanan } \\
\text { Varyans }\end{array}$ \\
\hline \multicolumn{8}{|c|}{ İçsel Doyum } \\
\hline 1 & İşten memnuniyet & 0,763 & & & & & \\
\hline 2 & Tek başına çalışabilme & 0,386 & & & & & \\
\hline 3 & Değişik işler yapabilme & 0,812 & & & & & \\
\hline 4 & Saygın kişi olabilme şansı & 0,529 & & & & & \\
\hline 7 & $\begin{array}{l}\text { Vicdana aykırı olmayan işler } \\
\text { yapma }\end{array}$ & 0,348 & & & & & \\
\hline 8 & Sabit iş imkanı & 0,347 & & & & & \\
\hline 9 & $\begin{array}{l}\begin{array}{l}\text { Başkaları için bir şeyler } \\
\text { yapabilme }\end{array} \\
\end{array}$ & 0,929 & 3,068 & $\begin{array}{c}16,11 \\
(\%)\end{array}$ & & & \\
\hline 10 & Kişileri yönlendirebilme & 0,809 & & & & & \\
\hline 11 & Kendi yeteneklerini kullanabilme & 0,781 & & & & & \\
\hline 15 & Serbest karar verebilme & 0,742 & & & & & \\
\hline 16 & Kendi yöntemlerini kullanabilme & 0,716 & & & & & \\
\hline 20 & Başarı hissi & 0,629 & & & & & \\
\hline
\end{tabular}

İçsel doyum ortalama: 4,52; Cronbach Alfa: 0,888

\begin{tabular}{|c|c|c|c|c|}
\hline \multicolumn{5}{|c|}{ Dișsal Doyum } \\
\hline 6 & Yönetici karar yeteneği & 0,825 & & \\
\hline 12 & İş ile ilgili karar verebilme & 0,346 & & \\
\hline 13 & Yapılan iş ve ücret & 0,949 & & \\
\hline 14 & Terfi olanağı & 0,830 & 7,621 & 40,11 \\
\hline 17 & Çalışma şartları & 0,649 & & $(\%)$ \\
\hline 18 & İş arkadaşlarıyla anlaşma & 0,546 & & \\
\hline 19 & Takdir görme & 0,720 & & \\
\hline
\end{tabular}

Dışsal doyum ortalama: 3,61; Cronbach Alfa: 0,801

\begin{tabular}{|c|c|c|c|}
\hline \multicolumn{4}{|c|}{ İş Doyum Ölçeği İçin Tanısal Testler } \\
\hline Determinant & 0,0003 & Açıklanan Varyans & $56,229(\%)$ \\
\hline Barlett Test & $948,8^{* * *}(\mathrm{df}=171, \mathrm{p}=0.0000)$ & Skewness & 0,213 \\
\hline KMO & $0,850 * * *(\mathrm{p}=0,000)$ & Kurtosis & $-0,228$ \\
\hline Ölçek ortalaması & 4,18 & Shapiro-Wilk & İst $=0,988 ; d f=101 ; p=0,489$ \\
\hline \multicolumn{4}{|c|}{ İs Doyumu Ölçeği Güvenirlik: Cronbach Alfa: 0,913 } \\
\hline \multicolumn{4}{|c|}{ Faktörler Arası Korelâsyon } \\
\hline \multicolumn{3}{|c|}{ İçsel Doyum } & Dişsal Doyum \\
\hline \multicolumn{3}{|c|}{ İçsel Doyum } & \\
\hline \multicolumn{3}{|c|}{ Dişsal Doyum } & 1 \\
\hline
\end{tabular}

Açıklamalar: ***\%1 düzeyinde istatistiksel olarak anlamlılığı ifade eder.

İş doyumu ölçeğinin ortalamalarına bakıldığında; içsel doyum ortalaması $(\overline{\mathrm{x}}=4,52)$ ile dişsal doyum ortalamasından $(\overline{\mathrm{x}}=3,61) \quad$ yüksektir. Genel iş doyum ortalaması $(\overline{\mathrm{x}}=4,18)$ dir. AFAD çalışanların orta düzeyde iş doyumuna sahiptir denilebilir. Ölçeklerin güvenirlilik düzeyini veren Cronbach alfa katsayılarının tümü 0,80 sınır değerinin üzerinde olup ölçek maddelerinin içsel tutarlılığının oldukça yüksek olduğu söylenebilir. İçsel doyumunun Cronbach Alfa değeri 0,888, dişsal doyumunun Cronbach Alfa değeri 0,801 ve ölçeğin geneli için Cronbach Alfa değeri 0,913'tür. İçsel doyum ile dişsal doyum, istatistiksel olarak anlaml, pozitif yönlü ve yüksek bir ilişki $(\mathrm{r}=0,637)$ içerisindedir (p<0,01) (bkz. Tablo 1).

Örgütsel sessizlik ölçeğinin geçerliliğini ve güvenirliliğini belirlemek amacıyla uygulanan ve sirasiyla AFA ile Cronbach Alfa testinin sonuçları Tablo 2'de verilmiştir. Uygulanan AFA sonucunda elde edilmiş tanısal testlerin sonuçları ile alt faktörler arası korelasyon analizi sonuçları tablonun alt k1smında görülmektedir. Verinin faktör analizine uyumlu olması için korelasyon matrisinin determinantının sıfıra eşit ya da en azından çok yakın olması, KMO değerinin 
0,70 üzeri olması ve Barlett testine göre temel hipotezin reddedilmiş olması gerekmektedir. Diğer tanısal testler ise faktörlerin üst yapının yüzde kaçını açıkladığını, ölçeğin ortalamasını, ölçeğin eğiklik ve basıklık değerlerini ve normal dağılıma ilişkin Shapiro-Wilk testi sonucunu vermektedir. Tanısal testlerin sonuçlarına göre korelasyon matrisinin determinantı 0'a çok yakın bir değerdir. Hesaplanan KMO değeri, 0.831 gibi oldukça iyi bir değerdir ve Barlett testi sonucuna göre korelasyon matrisinin birim matris ile aynı olduğu iddiasındaki temel hipotez de reddedilmiştir $(p=0.000)$. Ayrıca eğiklik ve basıklık değerleri makul sınırlar içerisinde olup
Shapiro-Wilk testinin sonucuna göre normal dağılım temel hipotezi reddedilememiştir (ist $=0,943$ ve $p=0,386$ ). Uygulanan AFA sonuçlarına göre genel olarak tüm değişkenlerin kuramsal olarak beklenilen faktörler altında toplandıkları ve ayrıca tüm değişkenlerin faktör yüklerinin de yüksek olduğu görülmektedir. AFA sonuçlarına göre, örgütsel sessizlik ölçeği 3 boyut (faktör)'tan oluşan bir yapıdır. Bu sonuçlara göre veri ve model uyumu sağlanmış olup yap1 geçerliliği bulunmaktadır. Ayrıca elde edilen 3 faktör, örgütsel sessizliğin üst yapısının varyansının yaklaşık \% 70,45'ini açıklamaktadır.

Tablo 2. Örgütsel Sessizlik Ölçeği İçin Geçerlik ve Güvenirlik Analizi Sonuçları

\begin{tabular}{|c|c|c|c|c|c|c|c|c|c|c|}
\hline \multirow[b]{2}{*}{ SN } & \multirow{2}{*}{$\begin{array}{c}\text { Faktörler ve } \\
\text { İfadeler (k1saca) }\end{array}$} & \multicolumn{3}{|c|}{ Faktör 1} & \multicolumn{3}{|c|}{ Faktör 2} & \multicolumn{3}{|c|}{ Faktör 3} \\
\hline & & $\begin{array}{l}\text { Faktör } \\
\text { Yükü }\end{array}$ & Öz. & Varyans & $\begin{array}{l}\text { Faktör } \\
\text { Yükü }\end{array}$ & Öz. & Varyans & $\begin{array}{l}\text { Faktör } \\
\text { Yükü }\end{array}$ & $\ddot{\mathbf{O z}} \mathbf{z}$ & Varyans \\
\hline \multicolumn{11}{|c|}{ Kabul Edilmiş Sessizlik } \\
\hline 22 & $\begin{array}{l}\text { Arkadaş kararlarına } \\
\text { güven }\end{array}$ & 0,878 & & & & & & & & \\
\hline 25 & $\begin{array}{l}\text { Gelişme } \\
\text { görmeme }\end{array}$ & 0,731 & & & & & & & & \\
\hline \multicolumn{11}{|c|}{ Kabul edilmiş sessizlik ortalama $=3,11$; Cronbach Alfa: 0,771} \\
\hline \multicolumn{11}{|c|}{ Savunma Amaçlı Sessizlik } \\
\hline 29 & Fikir paylaşmama & & & & 0,726 & 3,20 & $\begin{array}{c}23,72 \\
(\%)\end{array}$ & & & \\
\hline \multicolumn{11}{|c|}{ Savunma amaçll sessizlik ortalama=3,62; Cronbach Alfa: 0,841 } \\
\hline \multicolumn{11}{|c|}{ Örgüt Yararına Sessizlik } \\
\hline 30 & İşbirliğini koruma & & & & & & & 0,749 & \multirow{4}{*}{1,61} & \multirow{4}{*}{$\begin{array}{c}11,15 \\
(\%)\end{array}$} \\
\hline 31 & $\begin{array}{l}\text { Kurum } \quad \text { yararı } \\
\text { gözetme }\end{array}$ & & & & & & & 0,695 & & \\
\hline 32 & $\begin{array}{l}\text { Kurum } \\
\text { saklama }\end{array}$ & & & & & & & 0,940 & & \\
\hline 33 & $\begin{array}{l}\text { Kuruma } \quad \text { zararı } \\
\text { önleme }\end{array}$ & & & & & & & 0,942 & & \\
\hline \multicolumn{2}{|c|}{$\begin{array}{l}\text { KMO } \\
\text { Ölçek Ortalaması }\end{array}$} & 4,38 & & \multicolumn{2}{|c|}{ Shapiro-Wilk } & & 0,943 & $(\mathrm{df}=101, \mathrm{p}$ & $=0,386)$ & \\
\hline & & & & & & Örgüts & Sessizlik $G i$ & enirlik: $C$ & onbach & lfa: 0,850 \\
\hline & & & & ktörler Ara & sı Korelâsy & & & & & \\
\hline & & Kabul Ed & lmiş Ses & izlik & Savunma A & Amaçlı S & sizlik & Örgüt Y & rarına S & ssizlik \\
\hline & uul Edilmiş Sessizlik & & 1 & & & & & & & \\
\hline Sav & ma Amaçlı Sessizlik & & $24 * * *$ & & & 1 & & & & \\
\hline & üt Yararına Sessizlik & & $384 * * *$ & & & $386 * * *$ & & & 1 & \\
\hline
\end{tabular}
Açıklamalar: ***\%1 düzeyinde istatistiksel olarak anlamlılı̆̆ ifade eder.

Örgütsel sessizlik ölçeğinin ortalamalarına bakıldığında; kurum yararına sessizlik ortalaması $(\overline{\mathrm{x}}=5,95)$ ile kabul edilmiş sessizlik $(\bar{x}=3,11)$ ve savunma amaçlı 
sessizlik ortalamasından $(\overline{\mathrm{x}}=3,62)$ oldukça yüksektir. Genel örgütsel sessizlik ortalaması $(\overline{\mathrm{x}}=4,38)$ dir. AFAD çalışanların orta düzeyde örgütsel sessizliğe sahiptir denilebilir. Ölçeklerin güvenirlilik düzeyini veren Cronbach alfa katsayılarının tümü 0,70 sınır değerinin üzerinde olup ölçek maddelerinin içsel tutarlılığının yüksek olduğu söylenebilir. Kabul edilmiş sessizliğin Cronbach Alfa değeri (0,771), savunma amaçlı sessizliğin Cronbach Alfa değeri $(0,841)$, kurum yararına sessizliğin Cronbach Alfa değeri $(0,881)$ ve ölçeğin geneli için Cronbach Alfa değeri 0,850'dir. Savunma amaçlı sessizlik ile kabul edilmiş sessizlik, istatistiksel olarak anlamlı, pozitif yönlü ilişki $(r=0,424)$ içerisindedir. Kurum yararına sessizlik ile kabul edilmiş sessizlik, istatistiksel olarak anlamlı negatif yönlü ilişki $(\mathrm{r}=-0,384)$ içerisindedir. Kurum yararına sessizlik ile savunma amaçlı sessizlik, istatistiksel olarak anlamlı pozitif yönlü ilişki $(\mathrm{r}=0,386)$ içerisindedir $(\mathrm{p}<0,01)$ (bkz. Tablo 2).

Tükenmişlik ölçeğinin geçerliliğini ve güvenirliliğini belirlemek amaciyla uygulanan ve sirasiyla AFA ile Cronbach Alfa testinin sonuçları Tablo 3 'de verilmiştir. Uygulanan AFA sonucunda elde edilmiş tanısal testlerin sonuçları ile alt faktörler arası korelasyon analizi sonuçları Tablo'nun alt kısminda görülmektedir. Verinin faktör analizine uyumlu olması için korelasyon matrisinin determinantının sıfıra eşit ya da en azından çok yakın olması, KMO değerinin 0,70 üzeri olması ve Barlett testine göre temel hipotezin reddedilmiş olması gerekmektedir. Diğer tanısal testler ise faktörlerin üst yapının yüzde kaçını açıkladığını, ölçeğin ortalamasını, ölçeğin eğiklik ve basıklık değerlerini ve normal dağılıma ilişkin Shapiro-Wilk testi sonucunu vermektedir. Tanısal testlerin sonuçlarına göre korelasyon matrisinin determinant1 0'dır. Hesaplanan KMO değeri, 0.904 gibi oldukça iyi bir değerdir ve Barlett testi sonucuna göre korelasyon matrisinin birim matris ile aynı olduğu iddiasındaki temel hipotez de reddedilmiştir $(p=0.000)$. Ayrıca eğiklik ve basıklık değerleri makul sinırlar içerisinde olup Shapiro-Wilk testinin sonucuna göre normal dağllım temel hipotezi reddedilememiştir (ist $=0,983$ ve $p=0,083$ ). Uygulanan AFA sonuçlarına göre genel olarak tüm değişkenlerin kuramsal olarak beklenilen faktörler altında toplandıkları ve ayrıca tüm değişkenlerin faktör yüklerinin de yüksek olduğu görülmektedir. AFA sonuçlarına göre, tükenmişlik ölçeği 3 boyut (faktör)'tan oluşan bir yapıdır. Bu sonuçlara göre veri ve model uyumu sağlanmış olup yap1 geçerliliği bulunmaktadır. Ayrıca elde edilen 3 faktör, tükenmişliğin üst yapısının varyansının yaklaşık \% 64,81'ini açıklamaktadır.

Tablo 3. Tükenmişlik Ölçeği İçin Geçerlik ve Güvenirlik Analizi Sonuçları

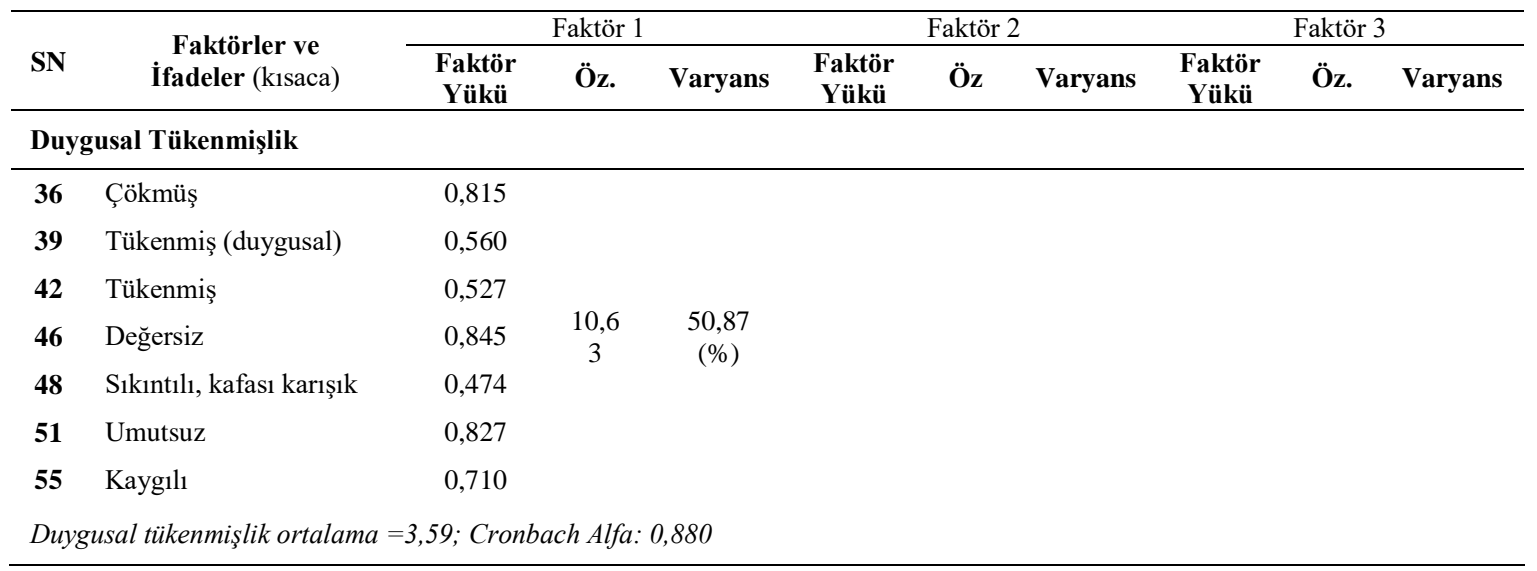


Tablo 3. (Devamı). Tükenmişlik Ölçeği İçin Geçerlik ve Güvenirlik Analizi Sonuçları

\begin{tabular}{lllll}
\hline Fiziksel Tükenmişlik & & & \\
\hline $\mathbf{3 5}$ & Yorgun & 0,936 & & \\
$\mathbf{3 8}$ & Tükenmiş (fiziksel) & 0,688 & & \\
$\mathbf{4 1}$ & Bitkin & 0,435 & & \\
$\mathbf{4 4}$ & Sağlıksız & 0,595 & 1,55 & 7,41 \\
$\mathbf{4 7}$ & Bıkkın & 0,649 & & $(\%)$ \\
$\mathbf{5 0}$ & Zayıf & 0,661 & & \\
$\mathbf{5 4}$ & Enerjik (R) & 0,804 & &
\end{tabular}

Fiziksel tükenmişlik ortalama=3,39; Cronbach Alfa: 0,859

Zihinsel Tükenmişlik

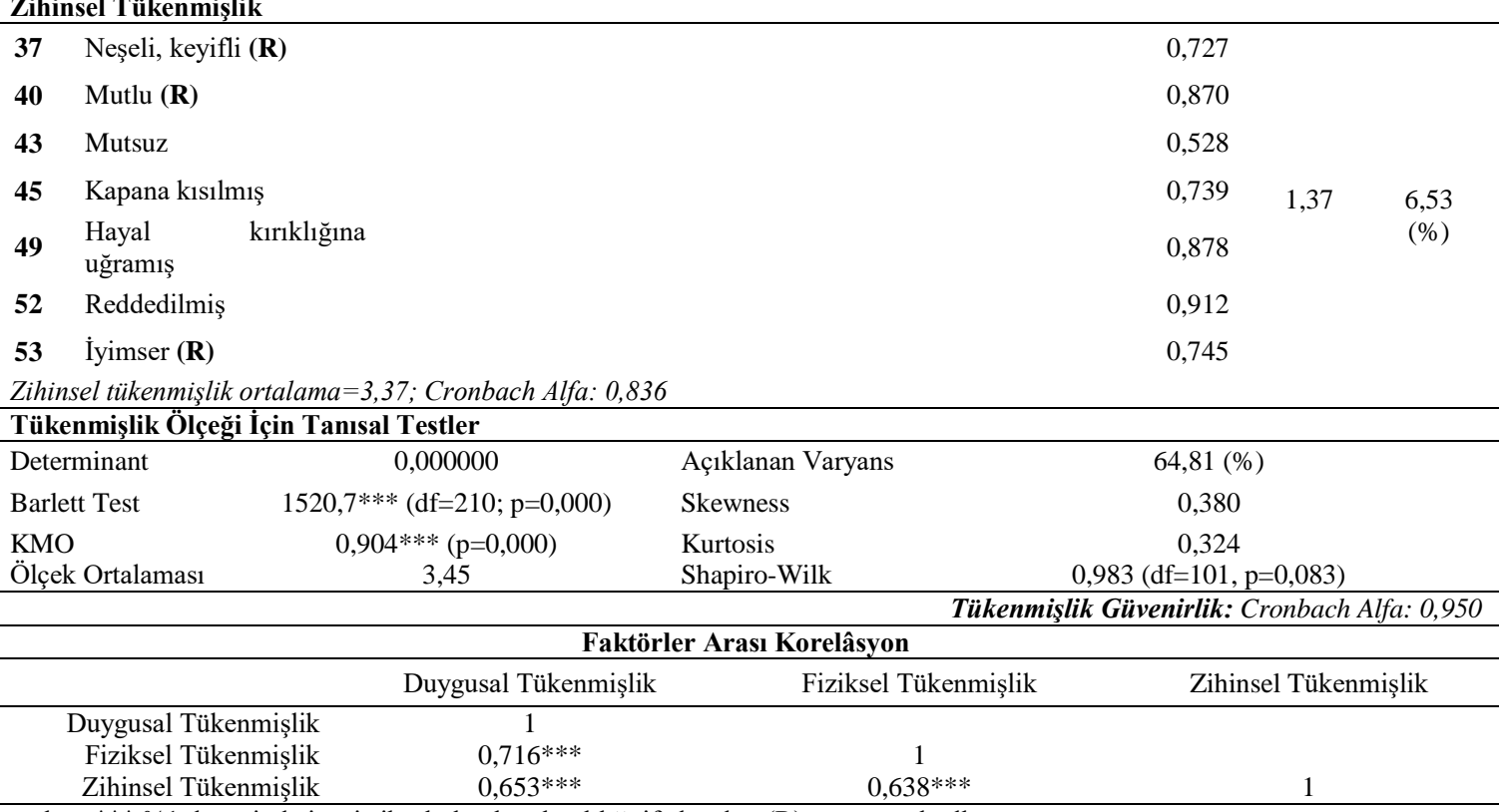

Açıklamalar: ***\%1 düzeyinde istatistiksel olarak anlamlılı̆̆ ifade eder. (R): soru ters kodlanmıştır.

Tükenmişlik ölçeğinin ortalamalarına bakıldığında; duygusal tükenmişlik ortalaması $(\overline{\mathrm{x}}=3,59)$, fiziksel tükenmişlik ortalaması $(\overline{\mathrm{x}}=3,39)$ ve zihinsel tükenmişlik ortalaması $(\overline{\mathrm{x}}=3,37)$ dir. AFAD çalışanları en fazla duygusal olarak tükenmektedir. Genel tükenmişlik ortalaması $(\bar{x}=3,45)$ dir. AFAD çalışanları kısmen tükenmiştir, denilebilir. Ölçeklerin güvenirlilik düzeyini veren Cronbach alfa katsayılarının tümü 0,80 sinır değerinin üzerinde olup ölçek maddelerinin içsel tutarlılığının oldukça yüksek olduğu söylenebilir. Duygusal tükenmişliğin Cronbach Alfa değeri 0,880, fiziksel tükenmişliğin Cronbach Alfa değeri 0,859, zihinsel tükenmişliğin Cronbach Alfa değeri 0,836 ve ölçeğin geneli için Cronbach Alfa değeri $\quad 0,950$ 'dir $\quad(p<0,01)$ Fiziksel tükenmişlik ile duygusal tükenmişlik arasında istatistiksel olarak anlaml, pozitif yönlü ilişki $(r=0,716)$ içerisindedir. Zihinsel tükenmişlik ile duygusal tükenmişlik arasında istatistiksel olarak anlaml, pozitif yönlü ilişki $(r=0,653)$ içerisindedir. Zihinsel tükenmişlik ile fiziksel tükenmişlik arasında istatistiksel olarak anlaml, pozitif yönlü ilişki $(r=0,658)$ içerisindedir. (Tablo 3 )

Çalışmada korelesyon ve reglesyon analizleri yapılırken değişkenlerin tüm alt boyutları tek boyut gibi değerlendirilmiştir. Korelasyon analizi sonuçları incelendiğinde, iş doyumu ve tükenmişlik arasında istatiksel olarak anlamlı, negatif yönlü ilişki $(r=-0,516)$ içerisindedir. İş doyumu ve örgütsel sessizlik arasında istatistiksel olarak anlaml, pozitif yönlü ilişki $(r=0,131)$ içerisindedir. Örgütsel sessizlik ve tükenmişlik arasında ise istatistiksel olarak anlamlı, pozitif yönlü ilişki $(r=0,127)$ içerisindedir.

Örgütsel sessizliğin, iş doyumu ile tükenmişlik arasındaki ilişki üzerindeki aracılık etkisini belirlemek amacıyla üç aşamalı bir regresyon analizi gerçekleştirilmiştir. Bu bağlamda öncelikle ilk aşamada bağımsız değişken olan iş 
doyumunun ile aracılık etkisi olduğu düşünülen örgütsel sessizlik arasındaki ilişki olup olmadığının belirlenmesi için regresyon analizi yapılması ve anlamlı bir ilişkinin belirlenmesi gerekmektedir. İkinci aşamada bağımsız değişken iş doyumu ile bağımlı değişken tükenmişlik arasındaki ilişki incelenmelidir. Üçüncü aşamada da bağımsız değişken olan iş doyumu kontrol altında iken aracı değişken örgütsel sessizlik ile bağımlı değişken tükenmişlik üzerine etkisi incelenmelidir. $\mathrm{Bu}$ üç aşamalı regresyon analizleri sonucunda aracilık etkisinin olup olmadığını ortaya koyabilmek için ikinci aşamada bağımsız değişken iş doyumunun bağımlı değişken tükenmişlik üzerindeki etkisinin tamamen ortadan kalkıp kalkmadığına bakılmalıdır. Ĕger ilişki devam ediyor ve anlamlılığını koruyorsa kısmi aracılık etkisinden; etki tamamen ortadan kalkıyor ve anlamlılık yitiriliyorsa tam aracılık etkisinden söz edilebilir. Ayrıca bu aşamada aracı değişken ile bağımlı değişken arasındaki ilişkinin anlamlılık düzeyini koruması da gerekmektedir. Belirlenen arac1lık etkisinin istatistiksel olarak anlamlı olup olmadiğından emin olmak amaciyla ayrica Sobel testi gerçekleştirilmekte ve test sonucuna göre aracı etkinin istatistiksel olarak da anlamlı olması beklenmektedir.

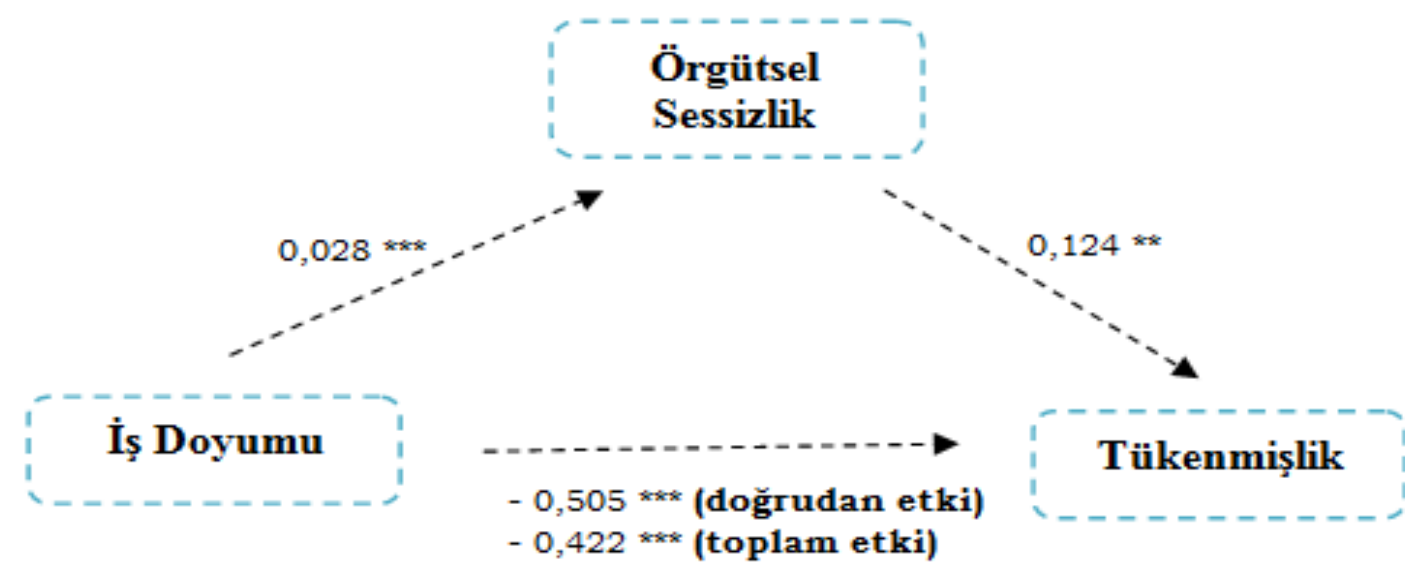

Açıklama: ** ve *** sırasıyla $\% 5$ ve $\% 1$ düzeyinde istatistiksel anlamlılığı ifade eder.

Şekil 1. Regresyon Analizi Sonuçları

Şekil 1'de iş doyumu, örgütsel sessizlik ve tükenmişlik arasındaki ilişkileri belirlemeye ve örgütsel sessizliğin aracılık etkisini ortaya koymaya yönelik olarak gerçekleştirilen regresyon analizlerinin sonuçlarını özet olarak vermektedir. Sonuçlar incelendiğinde AFAD çalışanlarının iş doyumunun örgütsel sessizlik düzeyleri üzerinde $\% 1$ düzeyinde istatistiksel olarak anlaml, zayıf ancak pozitif bir etkisinin $(\beta=0,028)$ olduğu görülmektedir. AFAD çalışanlarının iş doyumunun tükenmişlik üzerindeki etkisine bakıldığında; örgütsel sessizliğin aracı etkisi olmadığ 1 durumda AFAD çalışanlarının iş doyumlarının tükenmişlik düzeyleri üzerindeki doğrudan etkisi $(\beta=-0,505) \% 1$ istatistiksel anlamlılık düzeyinde anlamlı ve negatif yönlüdür. İş doyumu ile tükenmişlik düzeyi arasındaki ilişkide örgütsel sessizliğin aracı etkisi dikkate alındığı durumda iş doyumu ile tükenmişlik düzeyleri arasındaki negatif etki azalmakla beraber $(\beta=-0,422)$ bu etkinin istatistiksel anlamlılığ1 değişmemektedir. Son olarak da bağımsız değişken iş doyumu kontrol altında iken AFAD çalışanlarının örgütsel sessizlik düzeylerinin tükenmişlik düzeyleri üzerindeki etkisine bakıldığında $\% 5$ istatistiksel anlamlılık düzeyinde örgütsel sessizliğin tükenmişliği arttırdığı $(\beta=0,124)$ görülmektedir.

Tablo 4'de iş doyumu, örgütsel sessizlik ve tükenmişlik düzeyleri arasındaki doğrudan, dolaylı ve toplam etkilere ilişkin regresyon analizi sonuçlarını göstermektedir. 
Sonuçlara bakıldığında örgütsel sessizliğin aracı etkisi dikkate alınmadığında, iş doyumunun tükenmişlik üzerindeki etkisi negatif yönlüdür $(\beta=-0,505)$. Bağımsız değişkenin bağımlı değişkeni açıklama düzeyini veren R2'e göre iş doyumu tükenmişliğin \%27,3'ünü açıklamaktadır. Örgütsel sessizliğin iş doyumu - tükenmişlik ilişkisindeki aracılık etkisi (dolaylı etki) 0,083 düzeyinde olup üst ve alt güven aralığına (LLCI $=-0,022 ;$ ULLCI $=-0,1554$ ) sıfır değeri gelmediğinden bu etkiyi veren katsayının anlamlı olduğu söylenebilir.
Ayrıca aracı etki modelin açıklayıcılık gücünü (R2 değerini) zayıf da olsa $(\% 1,4)$ arttırmaktadır. Örgütsel sessizliğin aracılık etkisi de dikkate alındığında iş doyumunun tükenmişlik üzerindeki negatif etkisi devam etmekle birlikte bu etkinin $(\beta=-0,505$ 'den $\beta=$ 0,422 'e) azaldığı da görülmektedir. Özetle iş doyumu ile tükenmişlik arasındaki ilişkide örgütsel sessizliğin kısmi aracılık etkisi olduğu ve örgütsel sessizliğin bu iki olgu arasındaki negatif ilişkiyi zayıf da olsa $(\beta=0,083) \quad$ azalttığı ifade edilebilir.

Tablo 4. Doğrudan, Dolaylı ve Toplam Etkiler

\begin{tabular}{|c|c|c|c|c|}
\hline \multirow{2}{*}{ Etkiler } & \multicolumn{4}{|c|}{ İş Doyumu $\rightarrow$ Tükenmişlik } \\
\hline & Katsayı & t-değeri & p-değeri & $\mathbf{R}^{2}$ \\
\hline Doğrudan Etki & $\begin{array}{c}-0,505 * * * \\
(, 819)\end{array}$ & $-6,174$ & $\mathrm{P}<0,001$ & 0,273 \\
\hline Dolaylı Etki & $\begin{array}{c}0,083 * * * \\
(, 181)\end{array}$ & $\mathrm{LLCI}=-, \mathrm{C}$ & $\mathrm{I}=,-1554$ & $\Delta \mathrm{R}^{2}=+0,014$ \\
\hline Toplam Etki & $\begin{array}{c}-0,422 * * * \\
(, 084)\end{array}$ & $-5,139$ & $\mathrm{P}<0,001$ & 0,287 \\
\hline
\end{tabular}

Açıklamalar: *** \% 1 düzeyinde istatistiksel anlamlılı̆̆ı ifade eder. Dolaylı etki sonuçları 10.000 bootstrap ile elde edilmiştir.

Son olarak aracı etkiden kaynaklanan dolaylı etkinin istatistiksel olarak da anlamlı olup olmadığından emin olmak amaciyla Sobel testi gerçekleştirilmiştir. Tablo 3.11. uygulanan Sobel testinin sonucuna göre $\% 5$ istatistiksel anlamlılık düzeyinde aracılık etkisinden kaynaklanan dolaylı etki istatistiksel olarak anlamlıdır $(\mathrm{z}=2,113$ ve $\mathrm{p}=0,002)$. Dolaysiyla $\mathbf{H}_{1}$ hipotezi kabul edilmiştir.

AFAD çalışanlarının iş doyumunun tükenmişlik düzeylerine etkisinde örgütsel sessizliğin aracılık rolü istatistiksel olarak anlamlı bulunmuştur. Yapılan analizler değerlendirildiğinde iş doyumunun tükenmişlik üzerine etkisi negatif yöndedir. Örgütsel sessizliğin aracılık rolü dâhil edildiğinde de negatif etki devam etmekle beraber zayıf da olsa bu ilişkiyi yumuşatmaktadır.

İş doyumu, tükenmişlik ve örgütsel sessizlik ile ilgili araştırmalar incelendiğinde, afet alanında çalışan personellere yönelik çalışmaların ve bu üç değişkenin tek çalışmada birlikte irdelendiği sınırlı çalışma olduğu görülmüsşür.

\section{SONUÇ VE ÖNERIILER}

AFAD afet öncesinde önleme ve zarar azaltma çalışmaları, afet sırasında müdahale çalışmaları ve afet sonrasında iyileştirme çalışmalarını hızlı bir şekilde tamamlamayı amaçlamaktadır. $\mathrm{Bu}$ bağlamda afetler ile mücadele eden kurum ve kuruluşlar arasında iş birliği sağlayarak planlama, yönlendirme ve koordine etmek için disiplinler arası çalışma esas alan bir kurumdur. ${ }^{36}$ AFAD'ın insan kaynaklarını etkin ve verimli kullanılması büyük öneme sahiptir. $\mathrm{Bu}$ bağlamda AFAD çalışanlarının iş doyumu, örgütsel sessizlik ve tükenmişlik düzeylerinin belirlenmesi önem arz etmektedir. Konu ile ilgili literatür incelendiğinde, Akyol'un (2015) Erzurum Afet ve Acil Durum Arama ve Kurtarma Birlik personellerine yaptığ araştırma sonucuna göre 5'li likert iş doyumu ölçeğine verilen cevapların ortalaması 3,2771'dir. Bu çalışmada da 7'li iş doyumu 
ölçeğinde genel ortalama 4,18'dir. Çat'ın (2014) ve Koç'un (2019), acil yardım, kurtarma ve müdahale çalışanları üzerine yaptıği çalışmalarda, Karacaoğlu ve Çetin'in (2015) ve Vural'ın (2016) AFAD çalışanları üzerinde yaptığı araştırmalarda; AFAD personellerinin tükenmişlik seviyeleri orta değere yakın olduğu belirlenmiştir. $\mathrm{Bu}$ çalışmalarda da AFAD çalışanlarının tükenmişlik düzeyleri orta seviyeye yakın olduğu saptanmıştır. Bu durum personellerin hissedilir derecede tükenmişlik yaşamadıklarını gösterir. Bunun nedeni çalışanların insan hayatlarına dokunduğundan, insanlar yardım etme imkânı olduğundan tükenmeye karşı dirençli oldukları söylenebilir.

Birmiş, Ergeneli ve Oktay'ın (2018) afet ve acil durum yönetimi çalışanları üzerine yaptığı çalışmada örgütsel sessizlik düzeylerinin orta seviyeye yakın olduğu saptanmıştır. Turgut ve Akpolat'ın (2017) sağlık çalışanları üzerine yaptığı araştırmada ve Kaya'nın (2020) hemşireler üzerine yaptığ faktörleri arasında en yüksek ortalamanın örgüt yararına sessizlik olduğunu saptamışlar. $\mathrm{Bu}$ çalışmada da örgütsel sessizlik düzeyi orta seviyeye yakın olup, örgüt yararına sessizliğin kabul edilmiş sessizlik ve savunma amaçlı sessizliğe göre ortalamanın yüksek olduğu görülmüştür. AFAD çalışanlarının kurum yararına sessizliği tercih ettikleri söylenebilir.

Aslan Aydın'ın (2019), Koç'un (2019) ve Öztürk'ün (2018) sağlık çalışanlarına yönelik çalışmasına katılan personellerin tükenmişlik ile iş doyumu puan ortalamaları arasında negatif yönde anlamlı bir ilişki olduğu, Sarıtaş'ın (2015) itfaiye çalışanları üzerinde yaptığı araştırmada; iş doyum düzeyi ve tükenmişlik düzeyleri arasında negatif yönlü ve anlamlı bir ilişki olduğu belirlenmiştir. $\mathrm{Bu}$ çalışmada da AFAD çalışanlarının iş doyumu düzeylerinin tükenmişlik düzeyine etkisi anlamlı ve negatif yöndedir.

Karkı'nın (2017) ve Aktaş ve Şimşek'in (2015) kamu personelleri üzerine yaptığ 1 çalışmada örgütsel sessizlik ile iş doyumu arasında anlamlı negatif ilişki bulmuştur.
Demirtaş ve Nacar'ın (2018) öğretmenler üzerine yaptığı çalışmada örgütsel sessizlik ile iş doyumu arasında anlamlı ilişki bulunamamıştır. Egi'nin (2019) öğretmenler üzerine yaptığı çalışmada örgütsel sessizlik ile iş doyumu arasında anlamlı pozitif yönde ilişki bulmuştur. Doğan ve Kır'ın (2018) sağlık çalışanlarına yönelik yaptığı çalışmada örgütsel sessizlik ve tükenmişlik arasında anlamlı ilişki bulunmamıştır. Aktaş ve Șimșek'in (2015) kamu personelleri üzerine yaptığı çalışmada örgütsel sessizlik ile tükenmişlik arasında anlamlı negatif ilişki bulmuştur. Kahya'nın (2015) akademisyenler üzerine yaptığı Burulday'ı (2018) ve Çitli'nin (2015) öğretmenler üzerine yaptığ araştırmada örgütsel sessizlik ile tükenmişlik arasında pozitif yönde anlamlı ilişki bulmuştur. $\mathrm{Bu}$ çalışmada ise örgütsel sessizlik ile iş doyumu ve tükenmişlik arasında anlamlı pozitif yönde ilişki bulunmuştur. Sonuçların farklılaşmasının nedeni yapılan işin ve görev ve sorumluluklarının farklı olmasından kaynaklı olduğu düşünülebilir.

AFAD çalışanlarının iş doyumu, örgütsel sessizlik ve tükenmişlik arasında ilişkileri inceleyen çalışmaların kısıtlı sayıda olduğu saptanmış olup, iş doyumunun tükenmişlik düzeyine etkisinde örgütsel sessizliğin aracılık rolünü inceleyen çalışmaya rastlanmamıştır. Bu çalışmada iş doyumunun tükenmişlik düzeyine etkisinde örgütsel sessizliğin kısmi aracılık etkisi olduğu saptanmıştır.

Araştırma neticesinde ulaşılan sonuçlar değerlendirildiğinde ayrıca bazı hususlara değinmekte fayda vardır. Yapılan frekans analizi sonuçlarına göre çalışmaya katılan 101 AFAD çalışanının \%78,2'i mesleğini isteyerek tercih etmekle birlikte, bu çalışanların \%49,5'i zaman içerisinde sahada yaşamış olduğu sorunlardan dolayı mesleğini değiștirmek istemektedir. Bu durum ise bazı çalışanların mesleğine istekli başladıkları ve zamanla bu isteklerinin kırıldı $\breve{1}$ șeklinde yorumlanabilir. Yapılacak olan iyileştirme çalışmalar ile bu istekli çalışma halinin sürekliliği sağlanabilir. 
Çalışanların iş doyumlarının artması için çalışanların yeteneklerini ve yöntemlerini kullanabildikleri, iş ile ilgili kararlar verebildikleri, terfi olanakları, çalışma şartları gibi konularda çalışmalar yapılabilir. Çalışanların tükenmişlik düzeylerinin en aza indirilmesi için görevinin harici iş verilmemesi, yurt dişı eğitimleri, lojman, tayin gibi konularda özendirici çalışmalar yapılabilir. Çalışanların örgütsel sessizliklerinin en aza indirilmesi için fikir ve düşüncelerini özgürce ifade edebildikleri iş ortamı ve konuşmasını destekleyici çalışmalar yapılabilir.

Çalışanların iş doyumlarının artması için çalışanların yeteneklerini ve yöntemlerini kullanabildikleri, iş ile ilgili kararlar verebildikleri, terfi olanakları, çalışma şartları gibi konularda çalışmalar yapılabilir. Çalışanların tükenmişlik düzeylerinin en aza indirilmesi için görevinin harici iş verilmemesi, yurt dişı eğitimleri, lojman, tayin ve iş rotasyonu gibi konularda özendirici çalıșmalar yapılabilir. Çalıșanların örgütsel sessizliklerinin en aza indirilmesi için fikir ve düşüncelerini özgürce ifade edebildikleri iș ortamı ve konuşmasını destekleyici çalışmalar yapılabilir.

$\mathrm{Bu}$ çalışmada AFAD çalışanlarının iş doyumunun tükenmişlik düzeyine etkisinde örgütsel sessizliğin aracılık rolü incelenmiştir. Yapılacak yeni çalışmalara ulusal medikal kurtarma ekipleri, itfaiye birimleri, afet ile ilgili gönüllü sivil toplum kuruluşları da dâhil edilip iş doyumu, örgütsel sessizlik ve tükenmişlik düzeyleri arasındaki ilișki durumu incelenebilir. Bu çalışma, Adiyaman, Gaziantep ve Kilis personelleri ile sınırlı tutulmuştur. Sonuçlar tüm AFAD personellerine genellenemez ancak yine de fikir verebilir. Yapılacak yeni çalışmalarda diğer illerdeki AFAD çalışanlarında iş doyumu, örgütsel sessizlik ve tükenmişlik düzeyleri belirlenebilir.
1. Cukur, Y. (2017). Örgütsel Bağlılık ve İs Doyumu İlişkisi İstanbul İtfaiyesi Örneği. Yüksek Lisans Tezi, Nişantaşı Üniversitesi, Sosyal Bilimler Enstitüsü, İstanbul.

2. Eren, E. (2012). Örgütsel davranış ve yönetim psikolojisi. İstanbul: Beta Yayınları.

3. Kaya Göktepe, A. (2016). Tükenmişlik Sendromu. İstanbul: Nesil Yayınları.

4. Yücel, İ. (2012). “İş Tatmini İle Tükenmişlik Duygusu Arasındaki İlişki ve Algılanan Örgütsel Desteğin Bu İlișki Üzerindeki Etkisi-Sağlık Sektöründe Bir Uygulama’, Akademik Bakış Dergisi, 33, 1-20.

5. Cat, S. (2014). Acil Yardım, Kurtarma ve Müdahale Çalışanlarının Ruhsal Zeka ve Tükenmişlik Düzeylerinin Belirlenmesi Üzerine Bir Çalıșma: Gümüșhane İli Örneği Yüksek Lisans Tezi, Gümüşhane Üniversitesi Sosyal Bilimler Enstitüsü, Gümüşhane.

6. Koç, M. (2019). Acil Yardım, Kurtarma ve Müdahale Personellerinin Tükenmişlik Düzeylerinin Belirlenmesi Trabzon İli Örneği. Yüksek Lisans Tezi, Gümüşhane Üniversitesi Sosyal Bilimler Enstitüsü, Gümüșhane.

7. Karacaoğlu, K. ve Çetin, İ. (2015). “İş Yükü ve Rol Belirsizliğinin Calışanların Tükenmişlik Düzeyleri Üzerine Etkisi: AFAD Örneği'’. Nevşehir Hacı Bektaş Veli Üniversitesi SBE Dergisi, 5 (1), 46-69.

8. Vural, C. (2016). Tükenmișlik Sendromu ve Başa Cıkma Stratejileri: AFAD Ankara Birlik Müdürlüğünde Görev Yapan Sivil Savunma Arama ve Kurtarma Personeli Üzerine Bir Analiz. Yüksek Lisans Tezi, Ankara Üniversitesi Sağlık Bilimleri Enstitüsü, Ankara.

9. Aslan Aydın, Ö. (2019). Sağlık Calıșanlarında Tükenmişlik Sendromu ve İş Doyumu İlişkisine Yönelik Bir Araştırma. Yüksek Lisans Tezi, Türk Hava Kurumu Üniversitesi Sosyal Bilimler Enstitüsü.
10. Koç, İ. (2019). Sağlık Çalışanlarında Tükenmişlik Sendromunun İs Doyumu ve Depresyonla İliskisi. Tipta Uzmanlık Tezi, Sağlık Bilimleri Üniversitesi Haseki Sağlık Uygulama ve Araştırma Merkezi, İstanbul.

11. Öztürk, Z.D. (2018). Sağlık Calıșanlarının İs Doyumu, Kayg1 ve Tükenmişlik Düzeylerinin İncelenmesi. Yüksek Lisans Tezi, Işık Üniversitesi Sosyal Bilimler Enstitüsü, İstanbul.

12. Sarıtaş, Z. (2015). İzmir Büyükşehir Belediyesi İtfaiye Calıșanlarının İs Doyumu ve Tükenmişlik Düzeylerinin Analizi. Yüksek Lisans Tezi, Dokuz Eylül Üniversitesi Sosyal Bilimler Enstitüsü, İzmir.

13. Cakıcı, A. (2007). "Örgütlerde Sessizlik: Sessizliğin Teorik Temelleri ve Dinamikleri’, Çukurova Üniversitesi Sosyal Bilimler Enstitüsü Dergisi, 16 (1), 145-162.

14. Aydemir, S. ve Korkmaz, O. (2015). “Örgütsel Sessizlik ve Örgütsel Vatandaşlık Davranışı Arasındaki İlişkinin Belirlenmesine Yönelik Bir Araștırma', Yönetim ve Ekonomi Araştırmaları Dergisi, 13 (2), 140-165.

15. Milliken, F.J. and Morrison, E.W. (2003). "Shades of Silence: Emerging Themes and Future Directions for Research on Silence in Organizations", Journal of Management Studies, 40 (6), 1564-1568.

16. Benli, A. ve Cerev, G. (2017). “Örgütsel Sessizlik ve Tükenmişlik İlişkisi: Turizm Çalışanları Örneği',. Yönetim Bilimleri Dergisi, 15 (30), 411-433.

17. Aktaş, H. ve Şimşek, E. (2015). “Bireylerin Örgütsel Sessizlik Tutumlarında İș Doyumu ve Duygusal Tükenmișlik Algılarının Rolü', Uluslararası Yönetim İktisat ve İşletme Dergisi, 11 (24), 205-230. 
18. Bitmis, G, Ergeneli, A. ve Oktay, F. (2018). “Dönüsümcü Liderliğin Duygusal Bağlılık Üzerindeki Etkisinde İşören Sessizliğinin Rolü: Afet ve Acil Durum Yönetim İşgörenleri Üzerine Bir Çalışma”' Akdeniz İ.İ.B.F. Dergisi, 18 (37), 48-62.

19. Turgut, M. ve Akbolat, M. (2017). "Örgütsel Vatandaşlık Davranış1, Örgütsel Özdeşleşme ve Örgütsel Sessizlik İlişkisine Yönelik Sağlık Çalışanları Üzerine Bir Araştırma'. Araştırma Hacettepe Sağlık İdaresi Dergisi, 20 (3), 357-384

20. Kaya, B. (2020). Hemşirelerde Örgütsel Sessizlik Düzeyinin Duygusal Emek Üzerine Etkisinin Araştırılması Yüksek Lisans Tezi, Kayseri Üniversitesi Lisansüstï Eğitim Enstitüsü, Kayseri.

21. Kark1, A. (2017). Kamu Kurumlarında Örgütsel Sessizlik ile İş Tatmini İlişkisi Sivas İli Örneği. Yüksek Lisans Tezi, Cumhuriyet Üniversitesi Sosyal Bilimler Enstitüsü, Sivas.

22. Demirtaş, Z. ve Nacar, D. (2018). “Öğretmenlerin İş Doyumu ve Örgütsel Sessizlik Algıları Arasındaki İlișki’, Eğitim Yansımaları Dergisi, 2 (1), 13-23.

23. Egi, C. (2019). Örgütsel Sessizlik Ve Örgütsel Özdeșleșmenin İs Doyumunu Yordaması. (Yüksek Lisans Tezi), Marmara Üniversitesi İstanbul Sabahattin Zaim Üniversitesi Eğitim Yönetimi ve Denetimi Ortak Yüksek Lisans Programı, İstanbul.

24. Doğan, S. ve Kır, A. (2018). "Örgütsel Sessizlik, Tükenmişlik Sendromu ve Çalıșan Performansı İlișkisi”, Ömer Halisdemir Üniversitesi İktisadi ve İdari Bilimler Fakültesi Dergisi, 11 (4), 1-14

25. Kahya, C. (2015). “Örgütsel Sessizlik ve Tükenmişlik Sendromu İlişkisi', International Periodical for the Languages, Literature and History of Turkish or Turkic, 10 (10), 523-546.

26. Burulday, V. (2018). Ortaokullarda Görev Yapan Öğretmenlerin Örgütsel Vatandaşlık, Örgütsel Sessizlik ve Örgütsel Tükenmişlik Davranışları Arasındaki İlişkinin İncelenmesi. Yüksek Lisans Tezi, Frrat Üniversitesi Eğitim Bilimleri Enstitüsü Eğitim Bilimleri, Elazı̆̆.

27. Çitli, İ.İ. (2015). MBA-Genel İşletmecilik Örgütsel Sessizlik ile Tükenmişlik Arasındaki İlișki ve Bir Araştırma. Yüksek Lisans Tezi, Bahçeşehir Üniversitesi Sosyal Bilimler Enstitüsü, İstanbul.

28. Karasar, N. (1998). Bilimsel Araștırma Yöntemleri, Ankara: Nobel Yayınları.

29. Weiss, D, Dawis, R.V, England, G. W, and Lofquist, L. H. (1967). "Manual fort he Minnesota Satisfaction Questionnaire', Minessotta Studies in Vocational Rehabilitation, 22

30. Baycan, F.A. (1985). An Analysis of The Several Aspects of Job Sat I Sfact I on Between Different Occupationa Groups. Yüksek Lisans Tezi, Sosyal Bilimler Enstitüsü, Boğaziçi Üniversitesi, İstanbul.

31. Pines, A.M. and Aronson, E. (1988). "Career burnout: Causes and cures', New York: Free Press.

32. Çapri, B. (2006). "Tükenmişlik Ölçeğinin Türkçe Uyarlaması: Geçerlik ve Güvenirlik Çalışması”. Mersin Üniversitesi Eğitim Fakültesi Dergisi, 2 (1), 62-77.

33. DYNE Linn Van, ANG Soon. and BOTERO İsabel C.; (2003), "Conceptualizing Employee Silence and Employee Voice As Multi Dimensional Constructs", Journal of Management Studies, 40(6), ss. 1359- 1392.

34. Şehitoğlu, Y. (2010). Örgütsel Sessizlik Örgütse Vatandaşlık Davranışı ve Algılanan Çalışan Performans İlişkisi. Doktora Tezi, Gebze Yüksek Teknoloji Enstitüsü Sosyal Bilimler Enstitüsü, Gebze.
35. Kline, P. (1994). An Easy Guide To Factor Analysis. New York: Routledge

36. T.C. İçişleri Bakanlığ Afet ve Acil Durum Yönetimi Başkanlığı. (2021). "AFAD Hakkında". Erișim adresi: https://www.afad.gov.tr/afad-hakkinda (Erişim tarihi: 30.03.2021).

37. Akyol, H. (2015). Afetlere Müdahale Eden Örgütlerde İşgören Tatmini ile Başarı Algısı İlişkisi: AFAD Örneği. Yüksek Lisans Tezi, Gümüşhane Üniversitesi Sosyal Bilimler Enstitüsü, Gümüşhane. 